\title{
Sykehjemsmedisin møter sykehusgeriatri
}

\author{
Fra å være institusjoner med hovedvekt på pleie og omsorg er sykehjemmene i de senere år blitt betydelig \\ endret. Pasientene er blitt eldre og skrøpeligere, og et sammensatt sykdomsbilde stiller høye faglige krav til \\ kommunenes sykepleiere og leger. Vi beskriver her en samarbeidsordning mellom kommune og sykehus der \\ kjernen er et felles ønske om økt kvalitet i behandlingen av de geriatriske pasientene.
}

Med samhandlingsreformen (1) skjerpes kravene til landets sykehjem ytterligere. De forventes å kunne ta imot pasienter raskere fra sykehus og bidra med mer avansert behandling. I tillegg skal de yte gode tjenester innen forebygging og rehabilitering, ivareta pasienter med alvorlig demens og atferdsforstyrrelser samt gi palliativ behandling av høy kvalitet til mennesker i livets sluttfase.

Sykdomspanoramaet i sykehjem er bredt, og de faglige utfordringene store. Både politikere og helsepersonell har snakket mye om behovet for økt fagkompetanse, men til nå har det skjedd relativt lite. I mange sykehjem dekkes legetjenesten fortsatt av allmennleger i små stillingsbrøker, mens det i større kommuner er blitt mer vanlig med heltidsansatte sykehjemsleger. Med unntak av et par sykehjem i landet, hvor man kan oppnå inntil et halvt års tellende tjeneste $\mathrm{i}$ indremedisin og geriatri, meritterer det ikke i noe spesialiseringsløp «bare» å jobbe som sykehjemslege - uansett hvilken realkompetanse man har tilegnet seg. Dette er et stort problem hvis man er interessert $\mathrm{i}$ å rekruttere og beholde dyktige leger.

Legeforeningen vedtok nylig å opprette et kompetanseområde i alders- og sykehjemsmedisin - en formalisert, kompetansegivende etterutdanning for leger som allerede har en spesialitet (2). Dette blir forhåpentligvis et skritt på veien mot økt medisinsk kvalitet i sykehjem og kan bidra til å gi fagområdet større legitimitet og anerkjennelse. Men i hvilken grad vil det bidra til økt rekruttering av yngre leger som ennå ikke er ferdige spesialister?

Spesialisthelsetjenesten har en veiledningsplikt overfor kommunehelsetjenesten, og det burde være naturlig for geriatere å engasjere seg i sykehjemsmedisinen. De fleste norske geriatere arbeider i sykehus vårt mål er ikke å endre på det. Geriatri er først og fremst et sykehusfag, det er blitt tydeligere i de senere år ved at geriaterne arbeider stadig mer akuttorientert. Dette er det stort behov for, siden akutt syke gamle med komplekse helseproblemer profitterer på et geriatrisk tilbud i sykehus (3). Utviklingen bidrar imidlertid i liten grad til noe faglig løft for sykehjemmene, og vi mener derfor at det er viktig å etablere nye samarbeidsformer på tvers av tjenestenivåene.

\section{Samarbeidsordning}

Nittedal kommune, med drøyt 20000 innbyggere, har to sykehjem med til sammen
100 pasienter. Tidligere var det totalt en $60 \%$ legestilling fordelt på disse to sykehjemmene, men i 2007 ble rammen økt til 1,2 legeårsverk. Dette var fordelt på to leger, med 0,4 årsverk på den ene og 0,8 årsverk på den andre. Selv om bemanningen med dette ble styrket, var det ikke noe fagmiljø i kommunen relatert til sykehjemsmedisin eller geriatri. Det viste seg etter hvert vanskelig å få ansatt en ny lege med relevant kompetanse, og i 2008 tok derfor kommunen initiativ til samarbeid med spesialisthelsetjenesten. Nittedal kommune ligger i nedslagsfeltet til Akershus universitetssykehus, men der fantes det ikke noe geriatrisk tilbud. Det ble derfor i stedet etablert et samarbeid med Oslo universitetssykehus.

\section{«Mange kommuner sliter med dårlig konti- nuitet blant sykehjems- legene, og stillinger som meritterer i et spesialiseringsløp vil kunne bidra til bedre stabilitet»}

Geriatrisk avdeling ved Oslo universitetssykehus og Nittedal kommune fikk i fellesskap godkjent et tre års utdanningsløp for den ene av kommunens sykehjemsleger. Samarbeidsordningen trådte i kraft i november 2009. Avtalen innebærer at kommunens lege, ved å jobbe vekselvis i sykehjem og sykehus, i løpet av disse tre årene opparbeider seg to års tellende gruppe I-tjeneste i grenspesialiteten geriatri - samt to år i hovedspesialiteten indremedisin. Stillingen er forhåndsgodkjent av Legeforeningen som et forsøksprosjekt, og opplegget skal evalueres før man avgjør om nye leger skal kunne rekrutteres inn i tilsvarende ordninger.

\section{Utdanningsløpet}

Legen er ansatt $100 \%$ som sykehjemslege, men benytter $40 \%$ av sin arbeidstid ved Geriatrisk avdeling. Her roterer hun mellom avdelingens to sengeposter (akuttgeriatrisk post og akutt slagenhet), har poliklinisk tjeneste og deltar i internundervisning og på kurs på lik linje med ordinære utdanningskandidater.

Hun har også sin egen veileder i avdelingen. Som bytte for denne arbeidskraften stiller Geriatrisk avdeling en av sine overleger til disposisjon ved kommunens sykehjem tilsvarende $10 \%$ stillingsandel (én hel arbeidsdag annenhver uke) for supervisjon og veiledning. Overlegen går her visitt sammen med sykehjemslegen, med særlig oppmerksomhet rettet mot pasienter som representerer diagnostiske og terapeutiske utfordringer. I tillegg til denne supervisjonstjenesten, som fordeles mellom fire fast ansatte overleger, har sykehjemslegen anledning til å konferere med avdelingens geriatere når det ellers måtte være behov. Problemstillinger fra sykehjemmene kan også diskuteres på avdelingens morgenmøte.

For å kunne opprettholde stabil legedekning i kommunen ble det vanskelig å inkludere sykehjemslegen i den generelle indremedisinske vaktordningen ved sykehuset. Legen får derfor noe mindre akuttmedisinsk praksis enn de andre utdanningskandidatene i geriatri.

På den annen side gir dette bedre tid til fordypning og trening i spesifikke geriatriske problemstillinger. Vakttjeneste og øvrig indremedisinsk rotasjon må uansett senere gjennomføres etter vanlige regler for å oppnå godkjenning i hovedspesialiteten indremedisin. Sykehjemslegen arbeider hver dag med geriatriske pasienter og opparbeider seg bred erfaring gjennom disse tre årene. Arbeidsuken er variert, med tjeneste ved to ulike sykehjem (som inkluderer både korttids- og langtidsavdelinger) i tillegg til sykehustjenesten. Stillingen stiller således høye krav til fleksibilitet, selvstendighet og tverrfaglige samarbeidsevner - og gir legen en unik kompetanse som forhåpentligvis vil være til nytte for både primær- og spesialisthelsetjenesten også i fremtiden.

\section{Betydning for sykehuset og kommunen}

Samarbeidsordningen tilfører Geriatrisk avdeling ekstra legeressurser. Avdelingen har flere deltidsansatte assistentleger og har gode erfaringer med å samkjøre slike delte stillinger - for eksempel ved at to faste assistentleger deler arbeidsuken på en senge- 
post mellom seg. For å sikre kontinuitet og faglig kvalitet stiller dette krav til god kommunikasjon mellom legene, og det er viktig med en fast overlege for supervisjon. De ekstra ressursene kan også brukes til å frigjøre tid slik at andre assistentleger får en mer variert tjeneste, for eksempel i form av mer poliklinikk. En annen positiv effekt for avdelingen er økt kompetanse i sykehjemsmedisin. I tillegg til at sykehjemslegen er blitt en fast del av avdelingen, reiser nå flere av overlegene jevnlig på besøk til sykehjem. Der møter de andre sider av det geriatriske sykdomspanoramaet enn de gjør i sykehus, og får innsikt i primærhelsetjenestens utfordringer knyttet til diagnostikk og behandling av denne pasientgruppen. Disse erfaringene kan bidra til å bedre samarbeidet også med andre kommuner og bydeler. En utfordring med ordningen er at det kreves overlegeressurser for å yte supervisjon som avtalt i sykehjemmene, i tillegg kan det i perioder være utfordrende å tilby sykehjemslegen meningsfull tjeneste på deltid. Logistikken knyttet til arbeidsfordelingen $i$ avdelingen er derfor blitt mer kompleks.

Mange kommuner sliter med dårlig kontinuitet blant sykehjemslegene, og stillinger som meritterer i et spesialiseringsløp vil kunne bidra til bedre stabilitet. I slike spesialordninger kan det være fornuftig å legge opp til at legene må fullføre alle de avtalte årene for å oppnå tellende tjeneste. Slik øker sannsynligheten for å rekruttere oppriktig interesserte leger som ønsker å bli i stillingen over en lengre periode. I vårt tilfelle investerer likevel kommunen i sykehjemslegen ut fra en relativt kort tidshorisont. For å fortsette spesialiseringsløpet i geriatri må legen slutte i kommunen etter tre år, nettopp når hun er blitt best kvalifisert til jobben. For kommunens del tror vi likevel fordelene oppveier ulempene. Legen tilegner seg viktig kompetanse som kommer både pasientene og sykehjemspersonalet til gode i de årene samarbeidet pågår, og tilgangen til spesialister i geriatri ved kommunens sykehjem oppleves som svært nyttig. Overlegene gir faglige innspill av direkte betydning for enkeltpasienter, men også når det gjelder prosedyrer og problemstillinger av mer generell art. De har ved flere anledninger holdt undervisning på sykehjemmene og bidrar således på flere måter til entusiasme og økt faglig bevissthet også hos sykehjemmets øvrige ansatte.
Man kan diskutere hvordan slike spesialstillinger bør finansieres. Vi har valgt å giøre det enkelt, vi bytter rett og slett legeressurser. Selv om kommunen avgir mer lege enn de får (40\% sykehjemslege mot $10 \%$ overlege), så verdsettes kompetansetilførselen så høyt at kommunen er villig til det. Alternativt kunne man vurdert å dele lønnskostnadene mellom sykehus og kommune, siden kommunens lege tross alt utdannes til å bli sykehusspesialist. Vi frykter imidlertid at dette ville støtt på større byråkratiske stengsler.

\section{Et eksempel til etterfølgelse?}

For å drifte denne typen spesialordning kreves tilknytning til en geriatrisk avdeling der man har kapasitet på overlegesiden til supervisjon og veiledning ute i kommunen og der grenkandidaten kan tilbys klinisk tjeneste og undervisning som tilfredsstiller spesialitetskomiteens krav. For oss er den praktiske tilretteleggingen blitt løst uten store problemer, og vi ser for oss at en geriatrisk avdeling av vår størrelse burde kunne håndtere to slike utdanningsløp parallelt. Mindre geriatriske enheter vil trolig også kunne klare å tilby liknende ordninger - med tilpasning til lokale forhold. Befolkningsfremskrivninger tilsier at behovet for geriatere vil øke betydelig $\mathrm{i}$ årene fremover. Utdanningskapasiteten er imidlertid begrenset, og det er derfor ønskelig å se på alternative tilnærminger.

Behovet for bedre samarbeid mellom primær- og spesialisthelsetjenesten og økt fagkompetanse i sykehjem er minst like viktig. Det er mange mulige måter å møte disse utfordringene på, og geriatrien har allerede flere steder etablert forpliktende samarbeidsavtaler. Områdegeriatriske team, hvor et sykehusbasert, tverrfaglig team reiser rundt til kommunene og tilbyr hjelp og veiledning (4), er én type samarbeidsform. Et annet eksempel er TRUST-prosjektet (Tiltak for regional utvikling av samhandlingstjenester) på Lillehammer, hvor de har gjort forsøk med å ansette en «samhandlingslege» som både arbeider ved sykehusets geriatriske avdeling og ute i kommunen (5).

Vi tror ikke at vår modell vil kunne løse alle problemene knyttet til den manglende fagkompetansen i sykehjem. Ordningen kan imidlertid være et nyttig supplement til andre tiltak og bidra til bedre samarbeid mellom sykehusgeriatrien og sykehjems- medisinen. Vårt prøveprosjekt nærmer seg nå slutten, og det blir opp til Legeforeningen å bestemme om andre leger skal kunne forsøke seg i tilsvarende ordninger. Vi håper $\mathrm{det}-\mathrm{og}$ tror at flere geriatriske avdelinger og kommuner rundt om $i$ landet vil kunne finne gjensidig nytte av liknende avtaler.

\section{Rita Romskaug}

rita.romskaug@nittedal.kommune.no Nittedal kommune

Torgeir Bruun Wyller

Geriatrisk avdeling

Oslo universitetssykehus

Rita Romskaug (f. 1978) er sykehjemslege i Nittedal kommune og under spesialisering $i$ indremedisin og geriatri.

Ingen oppgitte interessekonflikter.

Torgeir Bruun Wyller (f. 1960) er spesialist $\mathrm{i}$ indremedisin og i geriatri, professor ved Universitetet i Oslo og overlege ved Geriatrisk avdeling, Oslo universitetssykehus.

Ingen oppgitte interessekonflikter.

Litteratur

1. St.meld. nr. 47 (2008-2009). Samhandlingsreformen. Rett behandling - på rett sted - til rett tid.

2. Etablerer kompetanseområde i alders-og sykehjemsmedisin. www.legeforeningen.no/id/ 178676.0 (23.1.2012)

3. Saltvedt I, Mo ES, Fayers P et al. Reduced mortality in treating acutely sick, frail older patients in a geriatric evaluation and management unit. A prospective randomized trial. J Am Geriatr Soc 2002 50: 792-8.

4. Sellæg, WF. Områdegeriatriske team - en modell for forpliktende samhandling mellom sykehjem og sykehus. Tidsskr Nor Lægeforen 2005; 125 1019-21

5. TRUST-prosjektet. www.trustprosjektet.no (8.1.2012).

Mottatt 12.1. 2012, første revisjon innsendt 23.1. 2012, godkjent 26.1. 2012. Medisinsk redaktør Merete Kile Holtermann. 